\title{
On Petersburg
}

\section{VLADIMIR NABOKOV}

[Bely's] greatest book, Petersburg, was written during the early years of this century. It is difficult to sum it up in a few words, because, as is the case with a truly great work of art, it itself represents the shortest possible exposition of all that the writer wanted to convey of it. Its manner and tackling of the subject, again as is the case with every truly great work of art, is unique and to be properly understood has to be experienced by reading.

And summing up such a book, as I am now about to do, is a thing I hate doing, for it amounts to a crippling of both the writer's intention and its realization. So now to get it over with as quickly as possible: the story proper is that of a young man, son of an important official/a senator, who, partly seduced by the temptations of terrorism, partly desperate because of a hopeless infatuation with a pretty but brainless woman and because of the silly things he has done in his desperation, agrees to introduce a time-bomb into his father's house. (The Father absentmindedly had removed it to the study. $)^{1}$ The bomb explodes with minor damage, and the young man, cured of his dangerous fancies, is seen living his mature years in Egypt, away from his family and from the place of his homicidal attempt. But the point of the book is not in this subject, however intricate and weird psychologically. The true hero of the book is the city by whose name it is called: Petersburg,

Unpublished lecture on Bely from the Berg Collection by Vladimir Nabokov. Copyright (C) 2015 by Vladimir Nabokov, courtesy of the Vladimir Nabokov Archive at the Berg Collection, New York Public Library, used by permission of The Wylie Agency LLC. This excerpt from an essay on Soviet literature was typed in English, with a title penciled in Russian, "Posle Bloka” (After Blok), by which it is catalogued. Unsigned, it has the appearance of a rough draft. This is also indicated by uncharacteristic repetitions in Nabokov's prose, which, however, convey his evident enthusiasm. Minor corrections in spelling, grammar, and style have been introduced. This excerpt elucidates Nabokov's often-cited statement that Petersburg is one of the four greatest novels of the twentieth century.

1 Last word crossed out. 
the phantasmagoric city built upon an unstable morass and upon the bones of the serfs who in the time of Peter the Great perished by the thousand working in the bogs up to their shoulders; the city always enveloped by dense fogs and often more like a ghost born out of the misty twilight than a real city of buildings and pavements; the city in whose mists mirages and phantoms are born to invade human minds erasing a borderline between truth and fantasy; the city whose beauty was sung by Pushkin, whose domineering spirit existing by itself and outside of the sense of all human volitions that blossom and sway on its mysterious mists, frightened Gogol, appalled Dostoevsky, enchanted Blok; the city whose mysterious self-centered spirit shows yet another facet in the mystic, almost superstitious awe of the Muscovite Bely.

There is for instance this passage:

Petersburg streets possess one indubitable property: they turn passers-by into shadows.

This we have seen in the example of the mysterious stranger.

Having come into being as a mental image, somehow he got connected with the senator's house; then reappeared upon the avenue, following closely the senator in our tale. ${ }^{2}$

Or this description of a crowded street:

All the shoulders constituted a dense slowly flowing stickiness; Alexander Ivanovich's shoulder glued itself onto it: got stuck in it—so to say; he followed his shoulder in conformity to the law of completeness of bodies; and thus he flung onto the Nevsky [Prospect].

What is a caviar grain?

There, the bodies on the sidewalk become one body, grains of the same caviar: and the sidewalks of Nevsky are so much sandwich-surface; his thought was immersed in the thinking capacity of the many-legged being, which was scurrying down Nevsky Prospect.

Then silently they lost themselves in contemplation of the numerous legs; while the sticky mass crawled: crawled along and shuffled on its many feet; it was pasted together of segments and every segment was a body.

2 This essay appears to contain one of the first partial translations of Petersburg. The novel first appeared in a complete English translation by John Cournos in 1959. Furthermore, it is quite clear that Nabokov is citing the shorter second edition of the novel, which was published in Berlin in 1922. A 1934 letter to Vladislav Khodasevich relates how "long ago" he "read it four times-in rapture." (I am grateful to Brian Boyd for this information from a Yale University archive.) 
There were no people on Nevsky; but there was there a crawling clamoring centipede; the damp space poured together the multiplicity of voices, forming a multiplicity of words; all words, intermingling, became merged in one sentence; and the sentence seemed senseless; it hung over Nevsky Prospect; and a black smoke of unrealities hung over it.

And out of these unrealities, the Neva [River], swelling, roared and beat against her massive granite parapets.

The crawling centipede is ghastly; down Nevsky, it runs through the centuries; and higher, above Nevsky—times are running out. There above, things are changing; but here-all is unchangeable; periods of time have their end. The human centipede has no end; all segments change but it itself is the same; the head is turned away from the railway station; the tail is turned off on the Morskaya Street; along Nevsky segment-footed links are shuffling along.

Here people cease to act as people. A weird doom takes over and directs their activities towards unpredictable ends. The book like Bely's other novels is written in an extremely subjective style, a kind of rhythmic prose, full of unprecedented sharp turns putting sometimes the most trivial words into such unwonted relief that, in their embarrassment, they begin to emit a new, often abstract, sense which you could hardly have ever thought them capable of doing. This queer rhythm and treatment of the language was eventually pushed by Bely to such extremes that his method began to obscure his intention instead of emphasizing it (Finnegans Wake). Bely was a very odd personality-just on the brink between genius and lunacy. He became wildly enthusiastic about absurd philosophies; during his last years and to his death he was an anthroposophist. Unfortunately, I cannot devote any more space to this lurid, exotic, aggravating, entrancing phenomenon. His first novel, The Silver Dove, would also merit a translation and a detailed analysis. His later work, as I have just mentioned, is often almost unintelligible. He has in common with James Joyce his absolute departure from, I would say his complete break with, all conventional forms of literature. With the exception of The Silver Dove, all that his novels (as Joyce's too) have in common with other novels is their being works of fiction written about the same characters from beginning to end and containing a number of pages usually understood to represent a "novel." Everything else: treatment of the theme, approach, style, every method involved differs widely from those of every other writer and is essentially individually and inimitably his own.

This very great writer, untranslated and quite unknown outside of Russia, was also a poet of great originality and talent. 
The time- the end of the XIXth century going into the beginning of the XXth—was a time "fin de siècle," not only because a numerical century was coming to an end but because it represented the final stage of that period, of that century of Russian culture which began with Pushkin and ended with Blok.

[...] Great artists in the true sense of the word are only those who added to the treasures of art something that has not been there before them. However attractive a book may seem to us at first sight, however original, we are bound for disappointment if it is not true art in the above-explained sense. Because some day, as we spend more time on reading and thinking, [the] time will come when we discover that true source, the artist who truly made the discovery and gave the world a new revelation, and if our former subject of admiration was not him, we shall soon realize that our worship was misplaced and that we had simply mistaken a reflection for the true object. Once a thing has been said, and said well, in a perfect fusion of subject matter and form, no other man can do it again and earn the laurels of a true artist unless he has added a new tremor, a new touch of beauty to what had been done by his predecessor. However, there exists another rather odd phenomenon: a man of no true literary genius may make a discovery, but never succeed in making a perfect work of art with it and then after him, another, a true genius, may come and pick up the poor discovery out of the mud of flat writing, and make of it something truly great and beautiful. Such was the case of Trediakovsky—a third-rate versifier of the XVIIIth century, contemporary of Lomonosov. Trediakovsky was the first poet convinced that Russian verse should be metrical, not syllabic. He was right, but he never wrote a good poem: it was Lomonosov who was the first to write real metric verse in Russian. Stream of consciousness was invented by an obscure French writer Dujardin some 50 years ago. ${ }^{3}$

Prepared by Brett Cooke, Texas A\&M University

3 Édouard Dujardin published Les Lauriers sont coupés (The Laurels Are Cut Down) in 1888. This statement suggests that Nabokov drafted this undated essay in the late 1930s or early 1940s. In a personal communication, Brian Boyd suggests this was likely in late 1940 or early 1941, when Nabokov wrote about a hundred lectures on Russian literature in hopes of teaching at American colleges. That Nabokov does not mention the 1941-45 blockade of Leningrad in his brief history of the city lends additional support to this dating. 
